今回，米国 mallinckrodt 社開発の抗 $T_{4}$ 抗体をプラス チック.試験管记固定化した“SPAC $\mathrm{T}_{4}$ RIA KIT”を使 用する機会を得たので，この kit に於ける基礎的並びに 小児正常域等についての検討を行ったので報告した。

\section{RAST 測定について}

\section{県立岥阜病院}

後藤 明 - 須田清輝

RAST (Radioallergo sorbent test) はアトピー性アレ ルギー性疾患患者のアレルゲン物質を発見するために， in vitro 法により検索するところに臨床的意義がある. 当院では昭和52年 4 月以降，約 220 名の患者（1患者当 り15項目）について RAST の測定を行ってきた．そこ で，(1) RASTの测定バラッキ，再現性等について検討 し，(2）RAST と血清 IgE 值との関係について調べた ので報告した.

\section{1. 当院における Ferrokinetics (体表計測) の方法}

福井県立病院放射線室

小沢ふじ子・小野幸一

Ferrokineties（鉄動態）の体表計測用試作コリメータ の有用性と体表計測の基本的なファクタについて報告す る。

1. 機器 5 インチスキャナ装置 (島津 $\operatorname{scc}-750 \mathrm{w}$ )を 使用した。

2. コリメータ 円錐型コリメータ（口径 $10 \mathrm{~cm}, 7 \mathrm{~cm}$, 高さ $7 \mathrm{~cm} ） \mathrm{LK}-35-\mathrm{A}$ を特注試作し，中央に位置ぎめ用 ランプをつけた。

3、測定部位 肝脾はあらかじめ肝シンチをとり，皮 膚面にマークをつ忷る，心缄は第 3 胁間胸骨左縁を中心 とし，骨髄は仙骨腸骨棘下 $5 \mathrm{~cm}$ 下を心として毎回同一 部位を測定.

4. 測定方法 標準線源 $\left({ }^{59} \mathrm{Fe} / \mu \mathrm{Ci}\right)$ を作成し測定器 の感度校正し，デスクリで測定.

5. 体表計測結果の表示法 真の鉄集積量 $=t_{1}$ に括け る臓器 count $-\frac{10 \text { 分後臓器 count }}{10 \text { 分後心葴 count }} \times t_{1}$ に和ける心臓comt [結論]

${ }^{59} \mathrm{Fe}$ 代謝は変動因子の多小検查法であるので，その因 子を出来るだけ固定化して愦差の少いデータ索作りたい．

(1)試作コリメータは目的に合致するが，承５少し深度 が樑くてもよい.

(2)スチャナ装置は最適で女る.

(3)測定coutを求めるだけで終らずグラフ化すべきであ る.

\section{IgE RAST 測定の意義}

大垣㠴民病院特殊放射線セン゙ター 小野又き子・金森学雄・木村得次
市川秀男・鶴田初男・樋口らづ子

IgE RAST (radioallergo sorbent test) が, アレル ギー疾患の診断に用いられるようになってから，まだ日 も浅いが，今回我々は，この IgE RAST 法たより現在 までに約 700検体に付き 4626 アレルダンを測定し，年令 別，季節別，男女別等を検討した。

年令別では，小览より幼坚の方が陽性度が高い，それ にくらべて成人は少ないことから，免疫が出さていると 考光られる，季節別では，春・秋と多く，男女の検数は 違らが，陽性率は変らないことがわかった。

外来である程度セレクトされてきた症例での陽性率で すから一般的統計とは言光ませんが，いくつかのレアギ

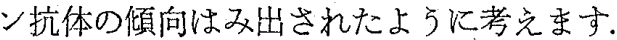

\section{SPAC T4 RIA KIT, T3 UP TAKE KIT の基 礎的検討について}

肢阜大学医学部附属病院中放部 伊藤慧正・島田正宏・市村勝博 岡田正昭・梶間正彦

\section{[目的及び結果]}

(1)incubation 条件について， T 4 RIA KITに於いては incubation Temperature $22-37^{\circ} \mathrm{C}$ incubation Time 60 分 $\mathrm{T}_{3}$ Uptake に於いては $20^{\circ} \sim 25^{\circ} \mathrm{C} 45 \sim 60$ 分が適応す る条件と思う。

(2) $\mathrm{T}_{4}$ RIA 值の正常域は 5.1 $120 \mu \mathrm{g} \%$ (M \pm S.D. 7.5

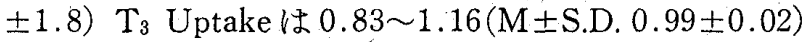
の範国と云它る。

(3)再現性は $\mathrm{T}_{4}$ RIAの Euthyriod で 8.84 S.D.) C.Vは 5.1\% $\mathrm{T}_{3}$ Uptake で $0.99 \pm 0.02(\mathrm{M} \pm$ S.D. $)$ C.V 1.3\%と良好であった。相関は $\mathrm{T}_{4}$ RIA とRes-OMat $\mathrm{T}_{4}$ との間で $\gamma=0.94$ 回帰式 $\mathrm{Y}=0.96 \mathrm{X}+0.14 \mathrm{~T}_{3}$ Uptake と Triosorb の間で $\gamma=0.79 \mathrm{Y}=0.81 \mathrm{X}+20.2$ と満足すべさ相関が得られた。（percent $\mathrm{T}_{3}$ Index にて 訪算)

\section{Thallium-201 による心筋 シンチグラフィー右室 負荷疾患の定量的評価一}

静岡目立こども病院核医学室

矢野正幸

静岡県立こども病院循環器科 主野博行

放射性同位元素 Thallium-201 は生体内でカリウムイ オンと類似した行動をとる事が知られて敊り，主として 冠血流量に応じ細胞の $\mathrm{Na}^{+}-\mathrm{K}^{+}-\mathrm{ATP}$ ase 活性により心 筋内へ摂取される。

我々は心室に対する生負荷和よび容量負荷の程度を経 静脈的に投与された ${ }^{201} \mathrm{~T} 1$ の心筋摂取量により定量的に 